\title{
PEMBERDAYAAN PETANI MELALUI BUDIDAYA TANAMAN SAYURAN DENGAN SISTIM POLYBAG PADA LAHAN PEKARANGAN DI DESA TAMAN BARU KECAMATAM SEKOTONG KABUPATEN LOMBOK BARAT
}

\author{
Wuryantoro $^{\left.1^{*}\right)}$ dan Candara Ayu ${ }^{1}$ \\ ${ }^{1}$ Program Studi Agibisnis Fakultas Pertanian Universitas Mataram \\ ${ }^{*}$ Korespondensi: wuryantorow@yahoo.com
}

Diterima 14 Mei 2020 / Disetujui 2 Juni 2020

\begin{abstract}
ABSTRAK
Permasalahan yang dihadapi oleh masyarakat Desa Taman Baru di Kecamatan Sekotong adalah rendahnya produktivitas lahan kering di daerah tersebut. Hal ini berdampak pada rendahnya sumber pangan dan pendapatan yang diterima oleh keluarga petani. Pengembangan tanaman sayuran di lahan pekarangan sistim polybag merupakan salah satu upaya meningkatkan produktivitas lahan dan pendapatan keluarga petani. Tujuan kegiatan pengabdian kepada masyarakat ini adalah meningkatkan pengetahuan dan keterampilan, kesadaran serta memotivasi keluarga petani dalam pemanfaatan lahan pekarangan sebagai sumber pangan dan pendapatan keluarga melalui pengembagan pupuk organik dan budidaya tanaman sayuran dengan sistem polybag. Dari hasil pelaksanaan kegiatan pengabdian ini ditarik kesimpulan bahwa para peserta penyuluhan merespon positif dan berpartisipasi secara aktif terhadap seluruh kegiatan yang diprogramkan. Transfer iptek dapat berjalan dengan baik dimana para peserta kegiatan pengabdian telah mampu membuat pupuk organik dengan memanfaakan bahan yang ada disekitar rumah, serta mampu melakukan budidaya tanaman sayuran dengan sistim polybag di halaman pekarangannya. Yang lebih penting lagi adalah para peserta penyuluhan menyadari bahwa pemanfaatan lahan pekarangan dengan menanami sayuran dengan sistim polybag dapat dijadikan sebagai sumber pangan dan pendapatan tambahan keluarga.
\end{abstract}

Kata Kunci: lahan pekarangan, pupuk organik, sayuran, polybag, pendapatan keluarga

\section{PENDAHULUAN}

Kemiskinan dan rendahnya produktivitas usahatani lahan kering di Kecamatan Sekotong, khususnya di Desa Taman Baru, merupakan mata rantai yang saling menguatkan dan berlangsung secara berkelanjutan. Kemiskinan akibat rendahnya pendapatan petani tersebut merupakan derivasi langsung dari rendahnya produktivitas lahan kering- marjinal yang umumnya telah terdegradasi, dimana pemulihan daya dukungnya memerlukan biaya yang banyak serta harus dilakukan secara berkelanjutan dalam jangka panjang. Di sisi lain, masyarakat petani di Kecamatan Sekotong memiliki berbagai potensi produktif yang dapat disinergiskan pemanfaatannya untuk menciptakan pendapatan. Pemanfaatan waktu luang, karene produktivitas rendah, serta 
pemanfaatan lahan pekarangan merupakan salah satu alternatif untuk meningkatkat produktivita keluarga petani.

Pekarangan bukan hanya untuk menciptakan keindahan dan kesejukan saja, tetapi lebih daripada itu adalah guna meningkatkan perekonomian keluarga masing-masing. Sedangkan jenis-jenis tanaman yang bisa ditanam dapat berupa berbagai sayur-sayuran, dan buahbuahan, obat-obatan, tanaman hias, dan lain sebagainya yang kesemuanya itu dapat menunjang kebutuhan sehari-hari dan selebihnya bisa dijual. Ketersediaan pangan dalam jumlah yang cukup sepanjang waktu merupakan keniscayaan yang tidak terbantahkan jika lahan pekarangan dimanfaat dengan baik (Dwiratna, 2016).

Secara umum, permasalahan dihadapi oleh masyarakat, khususnya di Desa Taman Baru dalam mengembangkan konsep pemanfaatan lahan pekarangan adalah kurangnya pengetahuan masyarakat terkait seberapa besar dampak pemanfaatan terhadap produksi dan pendapatan keluarga. Masalah lain yang dihadapi oleh masyarakat adal kurangnya pengetahuan dan pelatihan mengenai jenis tanaman yang mudah ditanam dan bernilai ekonomi, penyiapan media tanah, dan penyediaan pupuk organik dari bahan sekitar. Berdasarkan kondisi di atas, Tim Pengabdian Fakultas Pertanian Unram melaksanakan program penyuluhan dengan tema "Upaya Peningkatan Pendapatan Keluarga Petani Lahan Kering-Marjinal Melalui Pengembangan Tanaman Hortikultura di Lahan Pekarangan dengan Sistim Polybag di Kecamatan Sekotong Lombok Barat".

Tujuan kegiatan pengabdian kepada masyarakat ini adalah memberi penyuluhan dan pelatihan tentang berbagai potensi produktif yang dimiliki keluarga petani yang dapat digunakan untuk pengembangan usahatani tanaman hortikultura menggunakan sistem polybag di halaman/pekarangan rumah petani di Desa Taman Baru Kecamatan Sekotong. Melakukan demonstrasi/praktek pembuatan pupuk organik sesuai ketersediaan bahan baku di lokasi, penyiapan media tanam serta pengembangan usahatani tanaman hortikultura sistim polybag di halaman pekarangan.

\section{METODE KEGIATAN}

Kegiatan pengabdian ini
dilaksanakan di Desa Taman Baru tepatnya di Dusun Kelep Barat. Kawasan desa ini relatif lebih banyak memiliki daerah datar yang menjadi lahan pertanian dibandingkan desa lainnya dan masyarakatnya sangat mengutamakan mata pencaharian sebagai petani.

Sasaran/peserta kegiatan adalah keluarga petani dengan profil: tergolong petani kecil dan miskin, memiliki usahatani di lahan kering datar, tidak ada sumber mata pencaharian lain selain dari bertani, berdomisili di desa lokasi kegiatan, memiliki kemauan dan kemampuan untuk memperbaiki produktivitas tanah pertaniannya, bersedia dibina dan bersedia mengikuti dan melaksanakan seluruh program secara konsisten dan bertanggungjawab.

Pelaksanaan kegiatan pengabdian ini meliputi tahap sosialisasi dan penyampaian materi penyuluhan, tahap pelatihan yaitu praktek pembuatan pupuk organik dan budidaya tanaman sayuran sistim polybag.

\section{HASIL DAN PEMBAHASAN}

\section{Tahap Sosialiasi dan Penyuluham}

Sosialisasi ini dilakukan dengan cara menyebarkan informasi kepada masyarakat Desa Taman Baru, khususnya di Dusun Kelep, bahwa akan dilaksanakan 
kegiatan penyuluhan dan pelatihan terkait pemanfaatan lahan pekarangan dengan penanaman sayuran dengan sistim polybag. Sosialisasi dilakukan dengan dua cara, pertama secara kelembagaan yaitu melalui Kepala Desa Taman Baru sekaligus menyerahkan Surat Tugas, dan yang ke dua melalui Kepala Dusun Kelep Barat, selanjutnya oleh Kepala Dusun Kelep Barat, tim penyuluhan dikenalkan dengan masyarakat calon peserta kegaiatan penyuluhan.

Tahap sosialisasi dimaksudkan juga untuk melakukan identifikasi potensi sumberdaya pertanian lahan, potensi kerja keluarga serta identifikasi masalah yang dihadapi masyarakat di lokasi, serta mensosialisasikan program pengabdian. Selain itu kegiatan tersebut juga digunakan untuk menjaring kelompok keluarga petani (suami dan istri) yang akan dijadikan sebagai peserta. Kegiatan sosialisasi dan penyuluhan merupakan tahapan penting agar mau masyarakat memahami maksud tujuan dari diadakan kegiatan pengabdian oleh Tim Penyuluh Fakultas Pertanian Unram, serta untuk mengajak masyarakat mau berpartisipasi dalam kegiatan ini.

Tanpa keterlibatan masyarakat maka dapat dikatakan bahwa pelaksanaan kegiatan pengabdian ini tidak berhasil. Oleh karena itu metode penyuluhan metode digunakan, adalah dengan tutorial dengan menggunakan LCD yang disertai dengan gambar-gambar menarik agar peserta tidak bosan, lebih akrab dengan tim penyuluh, serta tertarik untuk melakukan diskusi dan tanya jawab. Materi penyuluhan yang disampaikan kepada peserta terkait manfaat lahan pekarangan sebagai sumber pangan dan sumber tambahan pendapatan keluarga, cara pembuatan pupuk organik dan teknik budidaya tanaman sayuran dengan sistim polybag.

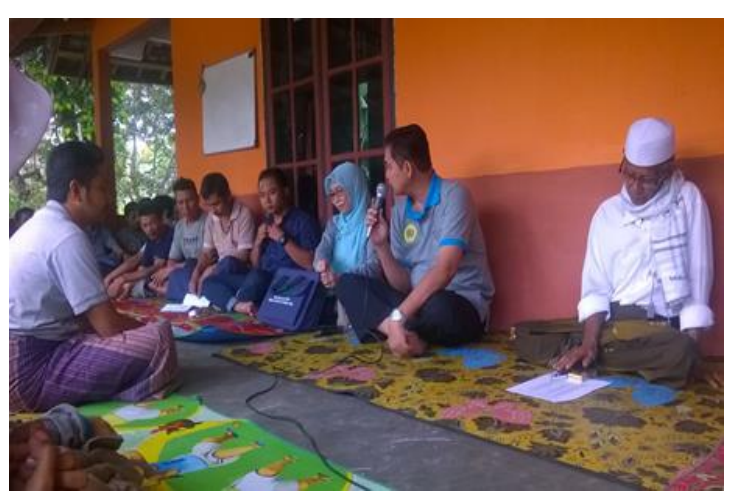

Gambar 1. Kegiatan Sosialisasi dan Penyuluhan

Tahap Praktek Pembuatan Pupuk Organik Setelah petani peserta penyuluhan memahami tentang manfaat dan teknik pembuatan pupuk organik melalui kegiatanpenyuluhan, selanjutnya dilakukan kegiatan praktek pembuatan pupuk organik. Pembuatan pupuk organik ini memanfaatkan banyaknya bahan baku yang tersedia di Desa Taman Baru (di lokasi kegiatan) seperti kotoran ternak sapi, serbuk gergaji, dedak, dan sekam padi. Dengan tersedianya bahan-bahan tersebut di lokasi kegiatan maka dapat memanfaatkan bahan tersebut menjadi bahan yang bermanfaat.

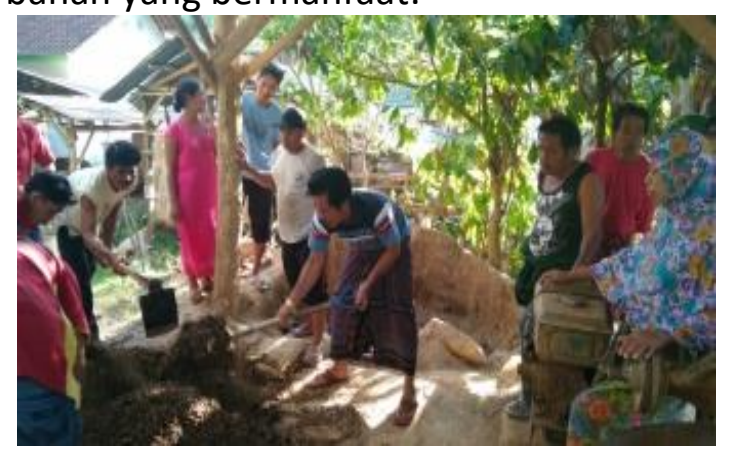

Gambar 2. Kegiatan Demo Pembuatan Pupuk Organik

Hasil identifikasi terkait respon petani terhadap kegiatan pembuatan pupuk organik, diketahui bahwa peserta sangat tertarik untuk dapat mengembangkan pembuatan pupuk organik secara mandiri, mereka menyadari betul bahwa pupuk organik 
sangat bermanfaat dalam meningkatkan kesuburan dan produktivitas lahan, serta hasil tanaman yang diperoleh baik dari sisi kesehatan. Setelah tahapan pembuatan pupuk organik, kegiatan dilanjutkan dengan pemanfaatan pupuk tersebut pada tanaman hortikultura dengan sistim polybag

\section{Pengembangan Budidaya Tanaman Sayuran Dengan Sistim Polybag}

Kegiatan sistim tanam dengan polybag, dimulai dengan kegiatan pembibitan. Ada jenis tanaman hortikultura yang dibudidayakan, yaitu tanaman pachcoy, cabe, terong, dan tomat. Pemiliahan lima jenis sayuran tersebut didasari alasan bahwa ke lima jenis sayuran yang banyak dikonsumsi dan mempunyai nila jual yang baik.
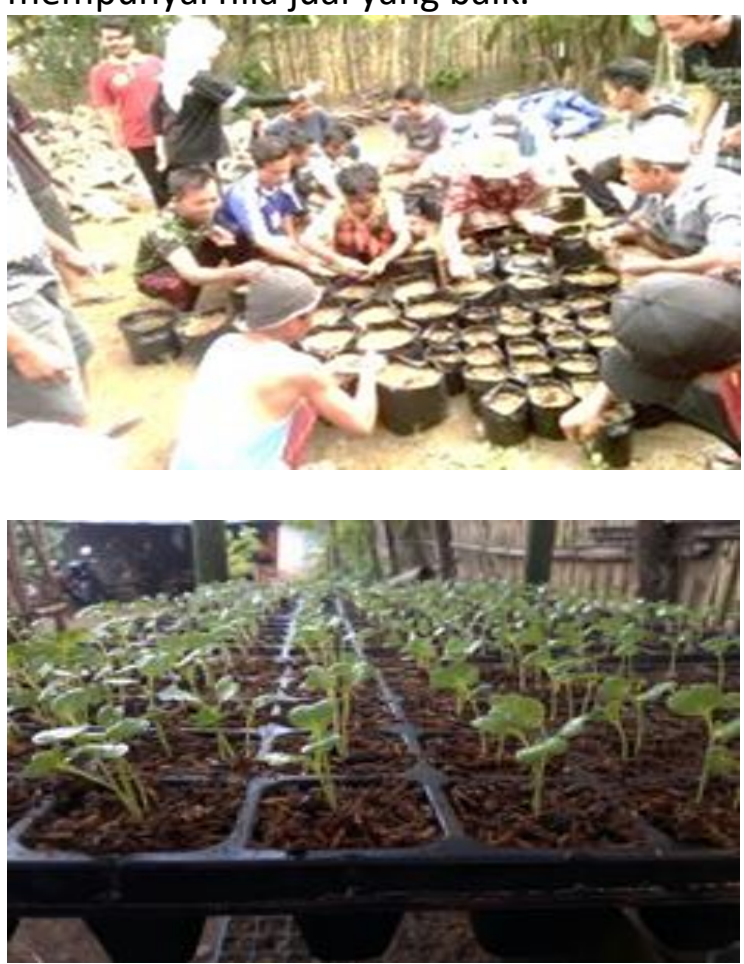

Gambar 3. Kegiatan pembibitan

Pembibitan dilakukan untuk mengurangi kemungkinan benih gagal berkembang. Wadah yang digunakan untuk pembibitan adalah Tray yang sudah disiapkan oleh Tim Penyuluh, selanjutnya setiap lubang Tray diberi tanah yang sudah dicampur dengan pupuk organik serta benih diletakkan agak ke dalam Tray tersebut. Kemudian dilakukan penyiraman secara berkala dan pastikan merata ke seluruh benih yang tersebar. Jika sudah memiliki daun, maka bibit siap dipindahkan ke dalam polybag.

\section{Penanaman Sayuran dengan Sistim Polybag di Lahan Pekarangan}

Setelah bibit sayuran cukup umur, kegiatan berikutnya adalah memindahkan bibit ke dalam polybag. Bibit yang di tanam merupakan bibit yang paling sehat dan sempurna.Bibit dikeluarkan secara hati-hati dan jangan sampai bibit rusak, selanjutnya ditanam dalam media polybag yang telah berisi tanah organik, hasil buatan peserta penyuluhan, yang telah disiapkan dan diari secukupnya.
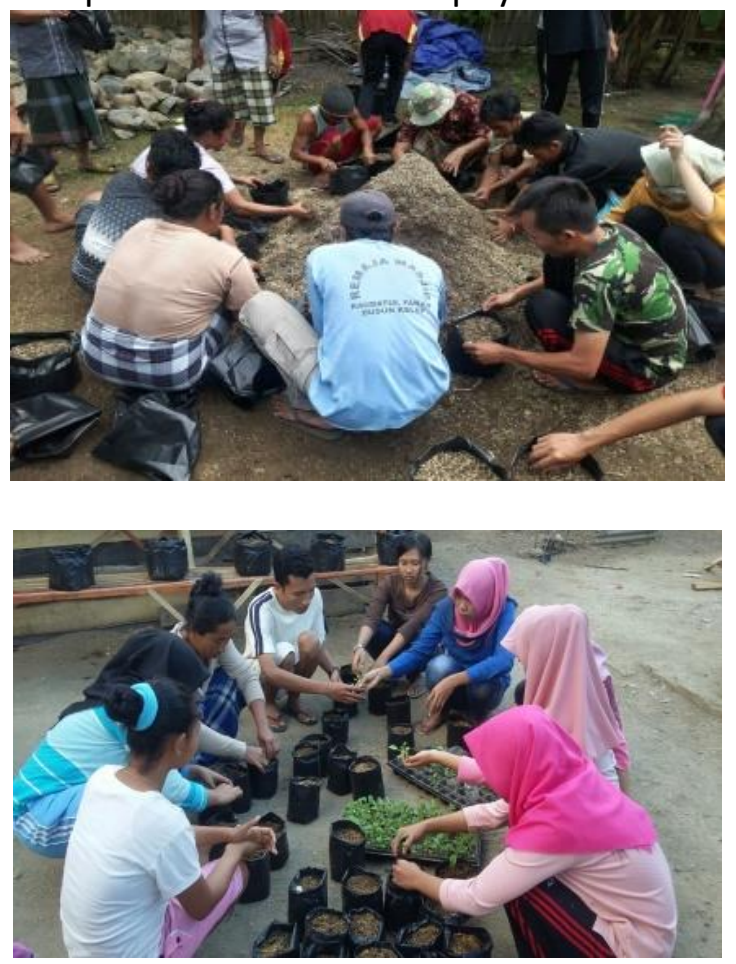

Gambar 4. Kegiatan penanaman sayuran ke media tanam polybag 

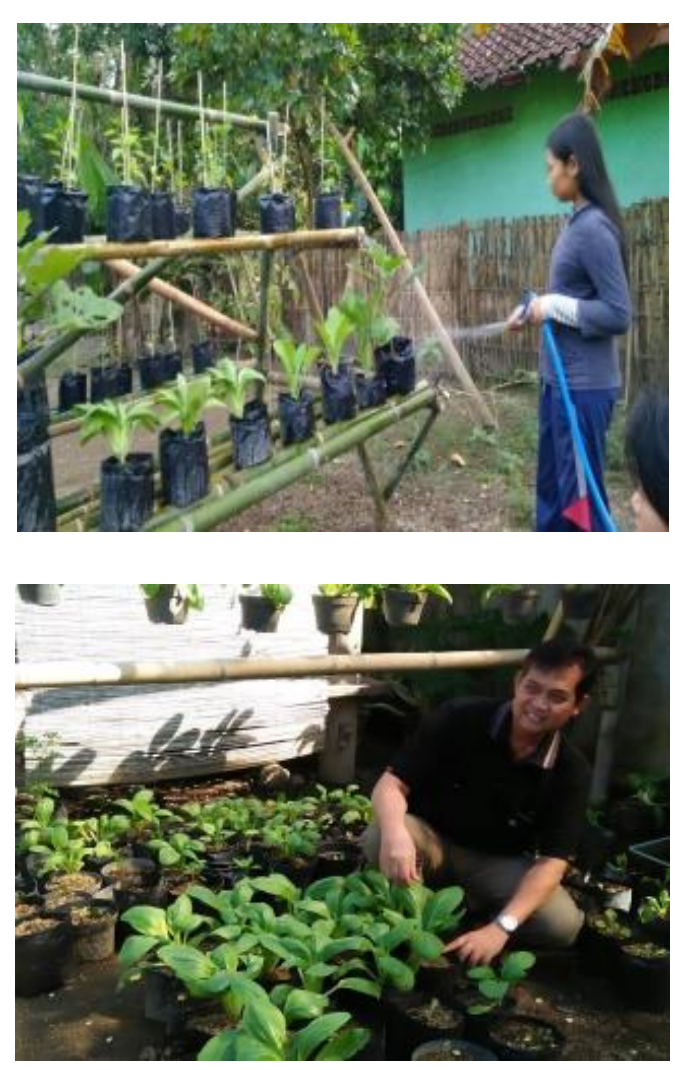

Gambar 5. Kegiatan pemeliharaan dan pemanenan sayuran

Gambar di atas menunjukkan bahwa membudidayakan tanaman sayuran di lahan pekarangan dengan sistim polybag dengan menggunakan rak, mampu menghasilkan banyak tanaman. Dengan meletakkan tanaman di rak secara bersusun, meskipun lahan pekarangannya sempit tanaman dapat dibudidayakan berbagai jenis sayuran dalam jumlah yang cukup banyak.

Dalam kegiatan penyuluhan ini pemeliharaan tanaman dilakukan dengan menggunakan obat-obatan pestisida organik, jika diperlukan, serta diari secukupnya. Pengairan pada tanaman sayuran dalam polybag disesuaikan dengan kebutuhan dari tanaman itu sendiri. Jika ukuran tumbuhan besar dan pertumbuhannya cepat, maka perlu dilakukan pengairan yang cukup kering. Jika tanaman sayuran mengalami kekurangan air, biasanya tanaman tidak akan tumbuh dengan sempurna dan menghasilkan hasil yang tidak baik. Pada kesempatan ini, dikarenakan keterbatasan waktu, tim penyuluh dan masyarakat baru menghasilkan (panen) pachcoy. Pachcoy mempunyai umur panen yang paling pendek yaitu sekitar 30-40 hari atau sekitar satu bulan, sedangkan tanaman sayuran terong, cabe, dan tomat memerlukan waktu sekitar 4 bulan.

Pemanfaatan lahan pekarangan dengan budidaya sayuram sistim polybag memberikan banyak manfaat, antara lain: dapat diusahakan dalam skala kecil atau rumah tangga, dengan memanfaatkan lahan pekarangan yang kosong untuk menyokong kebutuhan dapur maupun pendapatan keluarga, serta menambah keindahan alami lingkungan, dan menciptakan taman cantik di lahan terbatas, serta meningkatkan suplai oksigen di lingkungan sekitar. Dengan kesadaran masyarakat tentang gizi dan kesehatan yang semakin meningkat, potensi untuk mengkomersialkan tanaman sayuran juga semakin tinggi. Sehingga budidaya tanaman sayuran dengan sistim polybag dapat menjadi alternatif penting sebagai sumber pendapatan tambahan keluarga. Selain sayuran yang dihasilkan dapat dikonsumsi sendiri sehingga mengurangi pengeluaran rumahtangga.

\section{KESIMPULAN}

Dari hasil kegiatan yang telah dilakukan, maka dapat ditarik simpulan bahwa:

1. Kegiatan pengabdian ini dapat menambah pengetahuan warga tentang pentingnya pemanfaatan lahan sebagai salah satu wahana untuk memenuhi kebutuhan pangan dan peningkatan pendapatan keluarga.

2. Aspek psikomotorik peserta penyuluhan/pengabdian juga meningkat, dimana peserta 
penyuluhan telah mampu membuat pupuk organik dan melakukan budidaya tanaman sayuran dengan sistim polybag dengan baik.

\section{DAFTAR PUSTAKA}

Anonim, 2010. Ketahanan Pangan dan Penyuluhan. Tatangkostaman. blogspolybag.com.

Anonim, 2012. Karaktaristik-dan-CiriLahan-Kering.

https://www.scribd.com.

Anonom. 2017. Pemanfaatan-Pekarangan Untuk Ketahanan Pangan Keluarga. http:// www.rmol.co/read.

Ayu, C., Wuryantoro, Rosmilawati, dan Padusung. $2010 . \quad$ Model Pengentasan Kemiskinan Peserta Usahatani Konservasi Lahan Kering di Zona Tambang Emas Pulau
Lombok. Laporan Hibah Penelitian Strategis Nasional Tahun I. Fakultas Pertanian Universitas Mataram. Mataram.

Ayu, C. Wuryantoro dan Syarif Husni, 2016. Penguatan Kelompok Perempuan Berbasis Sinergitas Pemanfaatan Potensi Sumberdaya Agribisnis Lahan Kering dan Sumberdaya Ekowisata Bahari untuk Pengentasan Kemiskinan di Kecamatan Sekotong Lombok Barat. Laporan Hasil Penelitian Hibah Bersaing Tahun Idan Tahun II. Fakultas Pertanian Universitas Mataram.

Dwiratna, N.P.S, 2016. Pemanfaatan Lahan Pekarangan Dengan Penerapan Konsep Kawasan Rumah Pangan Lestari. Dharmakarya: Jurnal Aplikasi Ipteks Untuk Masyarakat. 